\title{
The Role of Foreign Presence in the Technology Transfer
}

\author{
Imen Daoud Naanaa and Fethi Sellaouti
}

\begin{abstract}
Many empirical studies have shown that a large part of the growth productivity is realized through foreign technology, so the objective of this paper is to test the role of foreign presence in the technology transfer through the analysis of its impact on productivity for Tunisian manufactory sector-based over the period 1990-2012. To this end, econometric equations that relate the total factor productivity (TFP), with foreign direct investment (FDI) that reflects technological spillovers will be tested. However, we use the generalized method of moments to determine the TFP.
\end{abstract}

Index Terms-Diffusion of technology, foreign direct investment (FDI), productivity.

\section{INTRODUCTION}

The role of foreign direct investment (FDI) as a factor in technology transfer is a precaution taken by many economists [1]. Thus Technology can be transmitted to developing countries thanks to the importance of the presence of foreign firms in this country. However, the entry of multinational firms leads to increased competition and creates pressure for domestic firms to become more productive. So the effect of competition implies that the technology introduced by foreign firms is an important source of technology spillover. We can also note that, according to the experiences of some foreign countries such as Australia, Canada, Mexico and Venezuela, the presence of foreign firms has a positive impact on productivity of local firms in the manufacturing sector and external effects are highly significant particularly on the growth.

In this context our objective is to analyze the role of foreign presence in the diffusion of technology and its effect on productivity growth in Tunisia, as a developing country.

This paper is organised as follows: Section II presents a literature review. Section III then examines the several estimations. Section IV summarizes the results and Section V concludes.

\section{LITERATURE REVIEW}

The literature on technology transfer shows that the effects of FDI (foreign direct investment) on the economy of host countries are various. [1]-[3] and more recently [4], in using an endogenous growth model argue that FDI helps to promote growth in developing countries by facilitating transfer of technology, increasing the skill level of workers and especially by the increase in exports and

Manuscript received June 15, 2013; revised August 22, 2013.

The authors are with Faculty of Economic Sciences and Management of Tunis (FSEGT), Tunisia (e-mail: daoudimen@yahoo.fr, fethi.sellaouti@fsegt.rnu.tn). competitiveness.

Similarly, the results of work [4] suggest that technology transfer is a channel through which growth can be promoted. [5], [6] argue along the same lines as the research and development activities conducted by foreign multinationals exert spillover effects on local firms that whether at the level of training of the workforce or in performance of inputs, but it is important to note that technology transfer with inflows of foreign direct investment will be beneficial to the host country that if it already has a fairly advanced level of technology or if it has a significant level of economic growth. [7] Shows that FDI and international trade activity of firms is a natural starting point of thinking about the international diffusion of technology.

\section{A. Domestic Firms and Multinational Firms}

According to [8], the multinationals firms have a spillover effect on domestic firms which provides the diffusion of technology through physical contact between the holder of technology and one who will receive it. Thus the knowledge brought by the multinational firms are likely to diffuse through links between suppliers and customers. However, imitation facilitates the upgrading and strengthening the R\&D. The Relations with the multinational firms are an effective channel of technology diffusion for the host country. In this context we find that multinational firms have an important role. First they behave as a demonstrator for stimulating local businesses. They constitute a new channel to export where learning occurs through observation [9].

Similarly [9] argue that "technology transfer between multinationals and their subsidiaries do not operate only through the machinery, equipment, patents and expatriate managers and technicians, but also through training of local employees of subsidiaries. This training applies to most employment levels." Furthermore, knowledge transfer can take place also through imitation and copying technologies and management methods and organization that would improve productivity. [10] Considers foreign direct investment (FDI) as an explanatory factor for the total factor productivity. [11], FDI involves technology transfer and in fact constitute a powerful source of learning whose benefits are spread across sectors by the mobility of the workforce. In addition to the import of capital goods and the purchase of technology and licensing, FDI becomes theoretically a crucial means to exploit the global knowledge and facilitate technological change and promote productivity growth [12].

\section{B. Empirical Works}

As part of the empirical work on the effects of FDI [4], using data on FDI flows from OECD countries to 69 developing countries found that FDI has a positive effect on growth in per capita income if the recipient country had attained a minimum threshold of human capital. 
According to [13] it appears that the diffusion of technology to the host country, measured by international patents, increases with the level of human capital of the country. Therefore according to [14] rich countries benefit from U.S. multinational firms in host countries while poor countries do not benefit as much. Similarly, [6] confirm the importance of R\&D and human capital. Their result (according to an analysis of the OECD countries) shows that R\&D ensures technological catch-up. [15] Studied the relationship between FDI and growth by using simultaneous equations on a panel of 84 countries ( 21 developed and 63 developing). Their results show that FDI promotes growth through direct effects but also through their interactions with human capital. Moreover, they found that the technological gap between developing and developed countries is likely to limit the positive effects of FDI. However, the presence of FDI is not a sufficient condition for the diffusion of technology to host countries. Indeed, convergence and catching-up are dependent then the absorption capacity of the host country (which is in its scientific and technological infrastructure), the technology gap between local and foreign companies, and the quality of local human capital as a key factor for economic growth in the host country must have an education system very efficient. Thus a well-trained and well qualified worker allows the transfer of technological and organizational knowledge from foreign firms and benefiting local businesses and therefore there will be an improvement in the overall effectiveness of economy. Thought, interest in FDI for host countries appears in his role as catalyst for development. Indeed, the contribution of FDI to growth and to strengthen the technological base of the host country depends largely on the economic and institutional context.

In fact, the empirical studies [9], [4] showed that FDI can contribute to productivity growth only if the technology gap between domestic and foreign firms is not too important, and when the absorptive capacity is sufficient in domestic firms. [16] Similarly suggests that FDI is becoming more integrated into corporate competitive strategies and national development policies. In summary, according to [9], it appears that countries relatively well endowed with human capital have the ability to attract foreign investment-intensive technology, which can increase the qualification of local labor. Moreover a number of recent studies do find qualified evidence for relationship between the FDI and technology diffusion [17] found strong evidence of productivity gains. technology transfer has generated profits for local firms, greater competition and lower prices [18] examine the impact of international and domestic technology transfers on, firms productivity performance in a sample of 448 Belgian innovating firms during 2003 - 2006. They find that firms engaging in international knowledge transfer strategies record substantially and significantly higher productivity growth. [19] Find that technology diffusion from US foreign affiliates has a positive and significant impact on labor productivity only if host countries have a minimum level of human development. [20] Find that FDI is an effective channel of technological transfer across borders. Also, the analysis uses a novel approach to take into account the possibility that physical distances can act as a barrier to economic and technological interactions amongst countries, by embedding a measure of geographical distance into two specific channels: international trade and FDI.

\section{EMPIRICAL STUdy: TECHNOLOGY SPILlOVER EFFECTS OF FDI AND ITS RELATIONSHIP WITH THE GROUTH OF TUNISIAN ECONOMY}

\section{A. Descriptive Statistics}

The Fig. 1 shows that firms with foreign participation accounted for 3068 firms in 2012 against 2339 in 2001.

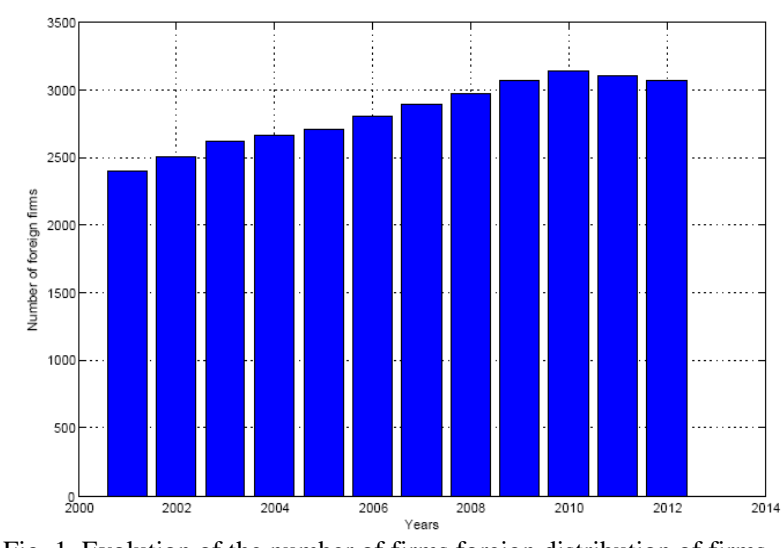

Fig. 1. Evolution of the number of firms foreign distribution of firms foreign-level manufacturing.

Concerning the partnership in manufacturing, we find that we have 1924 firms with foreign participation which are 1192 of them have capital to $100 \%$ foreign and 1634 of them are totally exporting, which representing $85 \%$ of firms in partnership. Analysis of the number of firms with foreign participation by country of origin reveals that France remains the predominant partner with $43 \%$ of firms with foreign participation. Italy comes second with $29 \%$ followed by Germany and Belgium with $9 \%$ sequentially and $7 \%$. We note that firms with higher foreign participation is in manufacturing, that where it is necessary to have advanced technologies. In this sense, foreign firms are more productive, have more information on foreign markets, and use the best manufacturing processes and new technologies.

The following Table I show that the sector that experienced the greatest attraction of foreign investors is the Textiles and Clothing. It represents $20.66 \%$ in 2006 and $7.21 \%$ in 2012. However, the Electrical and Mechanical sector becomes more attractive investment in 2012 with $37.6 \%$.

We note that it is the manufacturing sector that contributes most to growth at a relatively high level above 50\% particularly in the sectors "building materials" "textiles" and "chemistry", see Fig. 2.

\section{B. The Total Factor Productivity (TFP)}

The use of better production techniques and skills in human resources leads to an improvement in factor productivity and hence higher economic growth. So productivity measures the efficiency with which an economy transforms inputs "capital and labor" in the final product. Where Labor productivity is the gross domestic product (GDP) per hour worked or employment and Capital productivity is GDP per unit of capital. According to [11] TFP depends not only on the 
domestic stock of knowledge but also the stock of foreign knowledge. TFP measures allow an analysis of changes closely linked to the growth, production growth is the result of the growth of inputs and growth in productivity resulting from the use of improved production techniques (technological, organizational) and qualifications of human resources.

TABLE I: DISTRIBUTION OF FDI BY SECTOR

\begin{tabular}{|c|c|c|c|c|c|c|c|}
\hline & 2006 & 2007 & 2008 & 2009 & 2010 & 2011 & 2012 \\
\hline Various industries & 9.93 & 3.41 & 16.38 & 2.3 & 2.28 & 1.96 & $\overline{4.81}$ \\
\hline Food-processing & 5.03 & 8.11 & 2.35 & 3.3 & 10.25 & 5.62 & 9.23 \\
\hline Building Materials & 13.44 & 8.27 & 16.33 & 9.3 & 32.8 & 3.7 & 24 \\
\hline Mechanical, electrical and electronic & 11.48 & 30.5 & 15.59 & 27.08 & 25.13 & 46.6 & 37.6 \\
\hline Chemicals and rubber & 10.21 & 18.98 & 33.6 & 33.42 & 13.84 & 15.91 & 12 \\
\hline Textiles and clothing & 20.66 & 18.59 & 7.83 & 12,81 & 7.7 & 10.91 & 7.21 \\
\hline Leather and footwear & 13.7 & 5.39 & 5.14 & 4.36 & 0.61 & 4.38 & 4.2 \\
\hline Plastics & & 6.6 & 2.41 & 7.25 & 7.6 & 10.85 & 5.15 \\
\hline
\end{tabular}

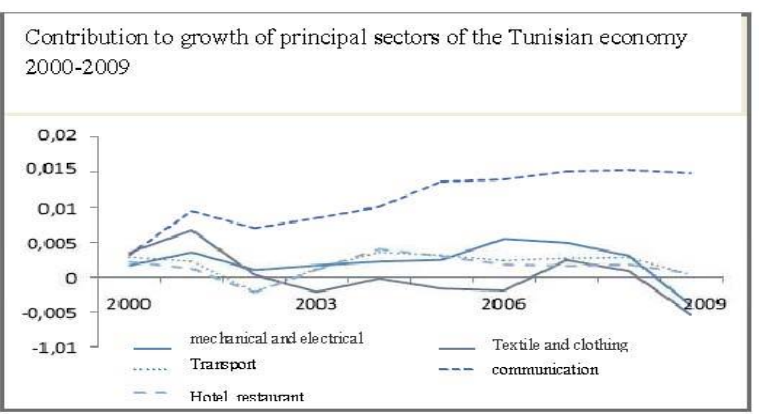

Fig. 2. Contribution to growth of principal sectors of the Tunisian economy 2000-2009 (African Development Bank (2012-2013)).

Measurement of total factor productivity allows us to see if technological diffusion leads to an acceleration of productivity growth at the sector level. Total factor productivity at the sector level is quite heterogeneous; its evolution is determined by both structural and cyclical factors (international situation, external openness, technology investments etc.). Before addressing the impact of new technologies on TFP in the manufacturing sector, we analyze first how this productivity assessed in previous years.

During the last years, the results recorded an improvement in the contribution of TFP to GDP growth from $26 \%$ during the period 1992-1997 to 45\% during the decade 1997-2006, which translates as the effort on technological progress and improvement of qualification of the workforce. The increase of inputs generates contributions of $30 \%$ for work and $24 \%$ for capital.

In the following, we present some results on the evolution of labor productivity, capital, and total productivity at the sectoral level manufacturing sector has a stagnation of the partial labor productivity, hovering around $2.2 \%$ over the period 1987-2007. The international situation has affected the textile and leather clothing that chemistry has affected their productivity $(-0.7$ for textile clothing leather 2002-2007 and $-2.0 \%$ for chemicals). Capital productivity has achieved an average annual increase of $2.7 \%$ over the period 1987 to 2007 with the investment effort in recent years and following a policy of targeting sectors with high added value.

According to the manufacturing sector, electrical engineering industries have been a substantial growth in the productivity of capital, due to the attractiveness and performance of this sector $(8.9 \%$ in average annual growth rate between 2002 and 2007), while the textile, clothing and leather sector has been on the same period a decline in productivity of capital of $1.6 \%$.

TFP chemistry sector grew at a high rate over the period 1987-1995 falling to $4.8 \%$ in $1996-2001$ and $1.6 \%$ in 2002-2007. It is also the case of mechanical and electrical industries, who after TFP growth of $2 \%$ and $5.7 \%$ respectively for the periods $1987-1995$ and 1996-2001, for 2002-2007 recorded a growth of $7.3 \%$ of the TFP. The textile leather clothing, after a growth rate of $4 \%$ and $3.2 \%$ found on the periods 1987-1995 and 1996-2001, has seen his TFP declined during the period 2002-2007 to $1.1 \%$. This decrease is related to the difficulties faced by this sector in the European market.

Measuring the TFP is based on the estimation of a function production. Our estimates are conducted on the basis of sectoral data (firms belonging to the Tunisian manufacturing sector), we used a production function of Cobb-Douglas as follows:

$$
Y=A K^{\beta} L^{\alpha}, \text { where } \beta+\alpha=1
$$

With $Y, K$ and $L$ are respectively the volume of production sector manufacturing, the stock of capital and number of workers employed in period t. The parameters $\alpha$ and $\beta$ are elasticities of production capital and labor respectively and $A$ is the technical progress or TFP. TFP can be written as follows:

$$
\mathrm{TFP}=\frac{y}{k^{\beta} l^{\alpha}}
$$

Transforming the above production function into logarithms allows linear estimation, and henceforth small letters will be used for logs. A simple standard estimation equation of the production function then looks as follows:

$$
Y_{i t}=\alpha \cdot l_{i t}+\beta \cdot k_{i t}+u_{i t}
$$

The residual of this equation is the logarithm of specific total factor productivity $A_{i t}$.

There are several methods on the estimation of TFP, we advance in the following some work that focus on measuring TFP.

Parametric methods are generally the most used. 
Nevertheless estimating the TFP may be made either by the (GMM), either by the semi-parametric method either by stochastic frontier. These three parametric methods can solve the problem of simultaneity.

\section{Empirical Test of FDI Technology Spillover}

We use the generalized method of moments to determine The TFP. Under this method the elasticities of value added with respect to capital and labor are highly statistically significant and amounted respectively to $37.18 \%$ and $60.62 \%$ According to the estimate the parameters of the production function, we pass to the calculation of total factor productivity. An analysis of FDI technology spillover effects raises the question whether FDI in Tunisia has all the aspects of the technology spillover effects for TFP ${ }^{1}$.

Model and data specification: Foreign direct investment, research and development investment, exportation and importation are chosen to explain variables, and the model adopted can be expressed as follows:

$$
\begin{gathered}
\ln \mathrm{TFP}_{i t}=a+b_{1} \ln \mathrm{FDI}_{i t}+b_{2} \ln \mathrm{R} \& \mathrm{D}_{i t}+b_{3} \ln X_{i t}+b_{4} \ln M_{i t}+\varepsilon_{i t}(2) \\
\quad \ln \mathrm{TFP}_{i t}=a+b 1 \ln \mathrm{FDI}_{i t}+b_{1-1} \ln \mathrm{FDI}_{i t-1}+b_{2} \ln \mathrm{R} \& \mathrm{D}_{i t} \\
+b_{2-1} \ln \mathrm{R} \& \mathrm{D}_{i t-1}+b_{3} \ln X_{i t}+b_{4} \ln M_{i t}+\epsilon_{i t}
\end{gathered}
$$

Whith TFP: is total factor productivity, $i$ means sector $(i=1 \cdots 5)$ and $t$ means period $(t=1990 \ldots$.2012)

- FDI: foreign direct investment

- RD: is research and development by sector

- $X$ : exportation by sector

- $M$ : importation by sector

The difference between these two writings is in the lag phase of FDI technology spillover effect on the effect of the total factor productivity. Lags may be appropriate because spillovers take time to materialize.

The datasets used in this paper are annual and based on manufacturing industries in five sectors for the period $1990-$ 2012 where we note:

- Sector 1 (S1: Food industry)

- Sector 2 (S2: Industry of building materials ceramic glass)

- Sector 3 (S3: Industry of electric and electronic)

- Sector 4 (S4: Industry of chemical)

- Sector 5 (S5: Industry of textile and clothing chemical.)

The data on the stock of capital, labor and GDP are collected from the institute of the quantitative study Data on foreign direct investment in each sector from the database of the agency promoting foreign investment in Tunisia (FIPA). Imports and exports of products by sector $^{2}$ are from the National Institute of Statistics (INS). Data on investment in R\&D from the Ministry of Scientific Research, Technology and Skills Development (MRSTDC).

Results and interpretation: The test results of FDI spillover effects can be seen in Table II. The results of the 5 regression equations show that the overall impact of FDI total

\footnotetext{
1 The study will focus on five manufacturing sectors (food industries, building materials industry ciramique glass, electrical appliances electronic industries chemical and textile clothing industry

${ }^{2}$ We considered the exports and imports of only three sectors for the unavailability of data for other sectors.
}

factor productivity is positive, and is significant. The results of the regression equations show that in sector one (Food industry), the first model shows that all variables are not significant except exportation $(X)$ when an increase at $10 \%$ in exportation promotes tfp (where $\mathrm{tfp}=\operatorname{lnTFP}$ ) by $16.06 \%$, after introduction lags.

(FDI(-1),FDI(-2), R\&D(-1), R\&D(-2)) the models fit better $R^{2}=0.641012$. For sector 2 and 4 (Industry of building materials ceramic glass and Industry of chemical) we find that all the variables are not significant. For sector 3 and 5 (Industry of electric and electronic and industry of textile and clothing chemical.) only importations that have positive and significant impact on tfp.

The second model where we denote by (') of sector 2 (IMCCV Industry of building materials ceramic glass), show that all variables are not significant, but model 2' fit better which indicates that FDI and R\&D technology spillover exist as factors that lag time. This model introduces FDI and the delayed second phase of the value of R\&D after the value of the second phase, the results show that this model fits best, so we can say that a $10 \%$ increase in FDI in ceramic materials and glass building sector leads to a $4 \%$ increase in tfp in this sector. This model introduces the lagged first phase of the value of FDI, and the current value of R\&D. However, from Table III we see that the research and development requires a period of time to have positive effects on tfp.

The results show also that the interaction between FDI and research and development ( $\ln$ FDI. $\ln \mathrm{R} \& \mathrm{D}$ ) has given a significant negative impact, but this can be explained by the absorption capacity remains low so that the technology and foreign innovations were not well absorbed.

In the electrical and electronic domestic appliances sector, model 3 show that importation $(M)$ is significant, but that FDI impact of total factor productivity does need a period of time before gradually playing out as we can see in model 3 ' which indicates that FDI technology spillover effects on the total factor productivity growth takes some time for local companies to absorb these techniques.

For the chemical industry sector we note that only the lagged first phase of the value of $R \& D$ has a positive and significant impact on total factor productivity. For the textile and clothing sector model 5 shows that the imports in this sector have a significant and positive impact on total factor productivity, while FDI and research and development requires a certain period of time to have positive effects on TFP (model 5') The absence of positive contribution of FDI to TFP can be explained by that FDI remains low and minor despite the encouragement changes in economic policy after 1980.

In addition we find that these investments are concentrated in traditional industries such as textiles, rather than sectors using new technologies where the contribution of advanced technologies in the total factor productivity will be higher.

The following is an empirical analysis of the relationship between FDI and manufactured economic growth.

\section{Determination of the Relationship between Growth and FDI in Manufacturing Sector}

An analysis of $\mathrm{FDI}_{m a}{ }^{3}$ technology spillover effects raises

\footnotetext{
${ }^{3}$ Foreign direct investment in manufacturing sector.
} 
the question whether FDI in Tunisia has all the aspects of the efficiency of the future. technology spillover effects, or has brought economic

TABLE II: ESTIMATION RESULTS

\begin{tabular}{|c|c|c|c|c|c|}
\hline \multirow{2}{*}{ Variable } & \multicolumn{5}{|c|}{ Data for manufacturing sector } \\
\cline { 2 - 6 } & Model 1 & Model 2 & Model 3 & Model 4 & Model 5 \\
\hline Constant & $S_{1}$ & $S_{2}$ & $S_{3}$ & $S_{4}$ & $S_{5}$ \\
\hline $\ln F D I$ & -0.000396 & $0.03705^{1}$ & -0.041347 & 0.017697 & -0.017096 \\
& $(-0.032608)$ & $(4.357384)$ & $(-1.657162)$ & $(1.077684)$ & $(-0.994687)$ \\
\hline $\ln R \& D$ & 0.006538 & 0.00684 & 0.004405 & 0.014877 & $-0.050653^{2}$ \\
& $(0.723275)$ & $(0.631446)$ & $(0.175669)$ & $(-0.313224)$ & $(-1.858175)$ \\
\hline $\ln X$ & 0.031153 & 0.0098 & 0.013001 & 0.092651 & 0.013966 \\
& $(1.362092)$ & $(0.250752)$ & $(0.172714)$ & $(0.645710)$ & $(0.232106)$ \\
\hline $\ln M$ & $0.160603^{1}$ & & 0.187863 & & 0.029402 \\
& $(3.313743)$ & & $(1.551581)$ & & $(0.307567)$ \\
\hline$R^{2}$ & 0.001842 & & $0.341216^{1}$ & & $0.468153^{1}$ \\
& $(0.032160)$ & & $(2.129987)$ & & $(3.458984)$ \\
\hline Values in brackets are the t-student & 0.475587 & 0.033773 & 0.451490 & 0.040273 & 0.782587 \\
\hline
\end{tabular}

1: The coefficient is significant at a risk of error $5 \%$

2: The coefficient is significant at a risk of error $10 \%$

TABLE III: ESTIMATION RESULTS

\begin{tabular}{|c|c|c|c|c|c|}
\hline \multirow[b]{2}{*}{ Variable } & \multicolumn{5}{|c|}{ Data for manufacturing sector } \\
\hline & Model 1' & Model 2' & Model $3^{\prime}$ & Model $4^{\prime}$ & $\begin{array}{l}\text { Model } 5^{\prime} \\
\end{array}$ \\
\hline & $S_{1}$ & $S_{2}$ & $S_{3}$ & $S_{4}$ & $S_{5}$ \\
\hline Constant & $\begin{array}{c}0.004184 \\
(0.8279)\end{array}$ & $\begin{array}{c}0.021174^{\top} \\
(0.0378)\end{array}$ & $\begin{array}{l}-0.012267 \\
(0.6612)\end{array}$ & $\begin{array}{l}0.03794 \\
(0.1419)\end{array}$ & $\begin{array}{r}-0.062180 \\
(0.0017)\end{array}$ \\
\hline $\ln F D I$ & $\begin{array}{c}0.007974 \\
(0.8144)\end{array}$ & $\begin{array}{c}0.040579^{1} \\
(0.0005)\end{array}$ & $\begin{array}{c}0.072282^{1} \\
(0.0109)\end{array}$ & & $\begin{array}{r}-0.042712 \\
(0.0487)\end{array}$ \\
\hline $\ln F D I(-1)$ & $\begin{array}{c}0.001385 \\
(0.9785)\end{array}$ & & $\begin{array}{c}-0.067747^{1} \\
(0.0306)\end{array}$ & $\begin{array}{c}-1.11 e^{(-9) 1} \\
(0.0259)\end{array}$ & $\begin{array}{c}0.083573^{1} \\
(0.006)\end{array}$ \\
\hline $\ln F D I(-2)$ & $\begin{array}{c}-0.008701 \\
(0.8302)\end{array}$ & & $\begin{array}{c}0.001737 \\
(0.9334)\end{array}$ & $\begin{array}{c}-1.17 e^{(-9) 1} \\
(0.0128)\end{array}$ & $\begin{array}{c}0.063342^{1} \\
(0.0240)\end{array}$ \\
\hline $\ln R \& D$ & $\begin{array}{c}0.028555 \\
(0.3963)\end{array}$ & & $\begin{array}{c}-0.199743 \\
(0.3143)\end{array}$ & & $\begin{array}{c}0.055502^{2} \\
(0.0617)\end{array}$ \\
\hline $\ln R \& D(-1)$ & $\begin{array}{c}0.005380 \\
(0.8649)\end{array}$ & & $\begin{array}{l}0.052975 \\
(0.2988)\end{array}$ & $\begin{array}{c}6.86 e^{(-9) 1} \\
(0.0219)\end{array}$ & $\begin{array}{l}0.034066 \\
(0.1791)\end{array}$ \\
\hline $\ln R \& D(-2)$ & $\begin{array}{c}-0.021287 \\
(0.6075)\end{array}$ & $\begin{array}{c}0.133208^{1} \\
(0.0338)\end{array}$ & $\begin{array}{c}0.045419 \\
(0.4039)\end{array}$ & $\begin{array}{c}2.12 e^{(-9)} \\
(0.3803)\end{array}$ & $\begin{array}{r}0.055462^{1} \\
(0.0458)\end{array}$ \\
\hline $\ln X$ & $\begin{array}{c}0.187223^{1} \\
(0.0334)\end{array}$ & & $\begin{array}{c}0.143562 \\
(0.3533)\end{array}$ & & $\begin{array}{c}0.075512 \\
(0.3857)\end{array}$ \\
\hline $\ln M$ & $\begin{array}{c}0.014986 \\
(0.8896)\end{array}$ & & $\begin{array}{c}0.367254^{\top} \\
(0.0346)\end{array}$ & & $\begin{array}{c}0.2116577^{1} \\
(0.034)\end{array}$ \\
\hline $\ln X \cdot \ln F D T$ & $\begin{array}{c}0.173389 \\
(0.3822)\end{array}$ & & $\begin{array}{c}-0.588240^{T} \\
(0.0053)\end{array}$ & & \\
\hline $\ln X \cdot \ln M$ & & & & & \\
\hline $\ln X \cdot \ln R \& D$ & & & $\begin{array}{l}1.363306 \\
(0.4063)\end{array}$ & & \\
\hline $\ln F D I . \ln R \& D$ & $\begin{array}{c}0.051816 \\
(0.8433)\end{array}$ & & & & \\
\hline $\ln F D I \cdot \ln M$ & $\begin{array}{c}-0.129478 \\
(0.4478)\end{array}$ & & & & \\
\hline $\ln M \cdot \ln R \& D$ & & & $\begin{array}{c}-0.511394 \\
(0.6124)\end{array}$ & & \\
\hline $\ln F D I \cdot \ln R \& D(-2)$ & & $\begin{array}{c}-0.303070^{1} \\
(0.0183)\end{array}$ & & & \\
\hline$R^{2}$ & 0.641012 & 0.624251 & 0.903354 & 0.683142 & 0.972419 \\
\hline
\end{tabular}

1: The coefficient is significant at a risk of error $5 \%$

2: The coefficient is significant at a risk of error $10 \%$

We consider in our study the manufactured sector so we consider $\mathrm{VA}_{m a}$ the value added of manufacturing sector and $\mathrm{FDI}_{m a}$ is the total foreign investment for this sector.

Cointegration ${ }^{4}$ analysis between $\mathrm{FDI}_{m a}$ and $\mathrm{VA}_{m a}$ : The following two variables $\mathrm{FDI}_{m a}$ and $\mathrm{VA}_{m a}$ are considered

\footnotetext{
${ }^{4}$ Cointegration analysis is a new econometric result since the 1980 s based on VAR methods could be used to test the longterm balanced relationship between two nonstationary time series. Cointegration tests must be carried out by the unit root test, only if the variables are the same as in the single-order, then the whole sequence can be used in the cointegration regression.
}

for this analysis. In the empirical analysis of data, the years from 1993 to 2012 are taken as a sample interval. To facilitate the study, a steady sequence is generated by taking the logarithm of the data sequence number, which does not change the characteristics of the variables. The logarithm of the variables of $\mathrm{FDI}_{m a}, \mathrm{VA}_{m a}$ are taken to get new variable sequences recorded as $\mathrm{FDI}_{m a}$ and $\ln \mathrm{VA}_{m a}$. The general regression model is as follows:

$$
\mathrm{VA}_{m a}=c(1)+c(2) \cdot \mathrm{FDI}_{m a}
$$

Unit root test: The ADF test is used to test the stability of variables, such as test results in Fig. 3, 4. That shows that all 
the level series of the variables are not smooth and their first-order differentials are stable, that is, all are I (1) sequences; the two long term relationship between the variables can be established through the next step of cointegration test.

\begin{tabular}{|c|c|c|c|}
\hline \multicolumn{4}{|c|}{$\begin{array}{l}\text { Null Hypothesis: DLFDI } I_{m e} \text { has a unit root } \\
\text { Exogenous: Constant } \\
\text { Lag Length: } 0 \text { (Automatic - based on SIC, maxlag=4) }\end{array}$} \\
\hline & & t-Statistic & Prob. ${ }^{*}$ \\
\hline \multicolumn{2}{|c|}{ Augmented Dickey-Fuller test statistic } & -3.278000 & 0.0293 \\
\hline Test critical values: & $\begin{array}{c}1 \% \text { level } \\
5 \% \text { level } \\
10 \% \text { level }\end{array}$ & $\begin{array}{l}-3.788030 \\
-3.012363 \\
-2.646119\end{array}$ & \\
\hline
\end{tabular}

"MacKinnon (1996) one-sided p-values.

Fig. 3. The stationarity test table of the $\mathrm{IDE}_{m a}$.

Null Hypothesis: DLVA ma has a unit root

Exogenous: Constant

Lag Length: 0 (Automatic - based on SIC, maxlag=4)

\begin{tabular}{lccc}
\hline \hline & & t-Statistic & Prob. ${ }^{*}$ \\
\hline Augmented Dickey-Fuller test statistic & -3.245442 & 0.0314 \\
\hline Test critical values: & $1 \%$ level & -3.959148 & \\
& $5 \%$ level & -3.081002 & \\
& $10 \%$ level & -2.681330 & \\
\hline
\end{tabular}

"MacKinnon (1996) one-sided p-values.

Fig. 4. The stationarity test table of the value added in the manufacturing sector.

Cointegration test: The results show that there is a unique cointegration relationship between the $\mathrm{FDI}_{m a}$ and $\mathrm{VA}_{m a}$ variables at the critical level of 5 percent, that is to say there is long-term stability and balanced relations between the two variables. The corresponding cointegration equation is as follows including the intercept and trends variables:

$$
\begin{aligned}
& \ln \mathrm{VA}_{m a}=0,009+0,12 \ln \mathrm{FDI}_{m a}(-1) \\
& +0,057 \ln \mathrm{FDI}_{m a}(-2)+0.073 . \mathrm{TREND}
\end{aligned}
$$

As can be seen, according to the test carried out, there is a positive correlation between $\mathrm{FDI}_{m a}$ and $\mathrm{VA}_{m a}$ in Tunisia and the two variables have a relationship of long-term dependency from the cointegration regression equation 5 .

Test results show that the increase in FDI ${ }_{m a}$ promotes growth of Tunisian manufacturing sector. Thus, would test show that there is a short-term relationship between value-added manufacturing and foreign direct investment in this sector. In the next section we try to analyze the effect of the degree of technology transfer on growth.

\section{ANALYSES IN TECHNOLOGY TRANSFER AND ECONOMIC GROWTH: DEMONSTRATION ANALYSIS}

\section{A. Definition of Degrees of Technology Transfer}

Based on the Tunisian technology transfer system we have constructed, an indicator called the degree of technology transfer is defined ${ }^{5}$, which reflects the general level of

\footnotetext{
5 See Sifeng Liu and Zhigeng Fang, Hongxing Shi and Benhai Guo, Theory of Science and Technology Transfer and Applications, ISBN: 978-1-4200-8741-3,2010 pp 238-254.
}

technology transfer. The definition is shown as follows:

$$
\mathrm{DTT}_{t}=\left(M_{t}+X_{t}+\mathrm{FDI}_{t}+\mathrm{RD}_{t}+\mathrm{FEC}_{t}\right) / \mathrm{GDP}_{t}
$$

DTT means Technology Transfer Level Indicators International technology transfer.

- FDI: Foreign direct investment

- FT: The introduction of foreign technology

- $\quad M$ : High-tech product imports

- FEC: Foreign economic cooperation

- $X$ : High-tech product exports

- GDP: Gross domestic product

\section{B. Definition and Measurement of Variables}

FDI: means the flow of foreign direct investment at time $t$. The introduction of technology means the transfer of technology from abroad to home (the technology denotes of bringing foreign technology knowledge and experience).

Therefore, we can define high-tech products with three main indicators (investment in $\mathrm{R} \& \mathrm{D}$, the proportion of scientific and technology talents and the technological level of products, the equipment for producing products, and the level of technology, etc.) Foreign economic cooperation includes external economic and technical aid ${ }^{6}$ the values for these variables (FDI, FT, $M$, FEC, $X$ and GDP) are collected from the World Bank.

The steady test of time series: According to the following Table, the unit root test of degrees of technology diffusion shows that the ADF statistics is minus 3.239873, less than 5 percent of the significant level of the critical value minus 3.029970 , so the original assumption is rejected. This variable has no unit root. That is a steady variable at first difference.

TABLE IV: The StATIONARITY TABLE OF THE DEGREE OF TECHNOLOGY TRANSFER

\begin{tabular}{|l|l|l|l|}
\hline $\begin{array}{l}\text { ADF test } \\
\text { statistic }\end{array}$ & -3.239873 & $1 \%$ & -3.831511 \\
\hline & & $5 \%$ & -3.029970 \\
\hline & & $10 \%$ & -2.655194 \\
\hline
\end{tabular}

TABLE V: THE STATIONARITY TEST TABLE OF THE GDP

\begin{tabular}{|l|l|l|l|}
\hline $\begin{array}{l}\text { ADF test } \\
\text { statistic }\end{array}$ & -3.742716 & $1 \%$ & -3.769597 \\
\hline & & $5 \%$ & -3.004861 \\
\hline & & $10 \%$ & -2.642242 \\
\hline
\end{tabular}

According to Table V, the unit root test of GDP shows that the ADF statistics is minus -3.742716 , less than 5 percent of the significant level of the critical value minus 3.020686, so the original assumption is rejected. It means that the GDP variable has no unit root, that is, this variable is a steady variable. In a word, through unit root test, the degree of technology transfer and GDP are the steady variables, so

\footnotetext{
${ }^{6}$ Foreign investment; foreign contracted projects, and labor cooperation; foreign joint ventures or enterprises with Chinese ownership; foreign production technology contracts; multilateral cooperation with the United Nations Development System and other international organizations; economic and technological aid from friendly countries.
} 
spurious regressions do not exist when the causality between the degree of technology transfer and the GDP is analyzed.

Analysis of causality in the degree of technology transfer and economic growth in Tunisia: Statistical data Eviews7.0 software is used to analyze causality between the degree of technology transfer and economic growth data. After testing, we can see in V that GDP is the Granger does not cause of the degree of technology transfer growth. However at the significant level of 10 percent, the degree of technology transfer is the Granger cause of GDP. As a result, we can say that at the 10 percent level technology transfer cause economic growth.

\section{CONCLUSION}

In this paper, we examined two issues regarding the productive performance of Tunisian manufacturing industries.

First, we focused on measuring sector-based TFP levels using GMM and analysis the role of foreign presence in the technology diffusion over the period 1990-2012. Estimates of our model show that a $10 \%$ increase in FDI in ceramic materials and glass building sector leads to a $4 \%$ increase in TFP in this sector.

In the electrical and electronic domestic appliances sector, the results shows that importation $(M)$ is significant, but that

FDI impact of total factor productivity does need a period of time before gradually playing out. (This indicates that a FDI technology spillover effect on the total factor productivity growth takes some time for local companies to absorb these techniques).

Same for the textile and clothing sector the estimates shows that the imports in this sector have a significant and positive impact on total factor productivity, while FDI and research and development require a certain period of time to have positive effects on TFP.

For the chemical industry sector we note that only the lagged first phase of the value of $R \& D$ has a positive and significant impact on total factor productivity so we can conclude that the research and development requires a period of time to have positive effects on TFP.

The results show also that the interaction between FDI and research and development $(\ln$ FDI. $\ln \mathrm{R} \& \mathrm{D})$ has given a significant and negative impact, but this can be explained by the absorption capacity remains low so that the technology and foreign innovations were not well absorbed. Also this can be explained by that FDI remains low and minor despite the encouragement changes in economic policy after 1980 .

In addition we find that these investments are concentrated in traditional industries such as textiles, rather than sectors using new technologies where the contribution of advanced technologies in the total factor productivity will be higher.

The result shows that, in global, there is a positive correlation between foreign direct investment and growth in the Tunisian manufacturing sector and the two variables have a relationship of long-term dependency from the cointegration regression equation 5 . Test results show that the increase in $\mathrm{FDI}_{m a}$ promotes growth of Tunisian manufacturing sector. wold test showed that exist a short-term effect. There is long-term stability and short-term effect too between $\mathrm{VA}_{m a}$ and $\mathrm{FDI}_{m a}$. So we have found that the degree of technology transfer cause economic growth. Hence, we have seen that the transfer of technology can occur through several channels, however, in this article we have focused on the importance of FDI in technology diffusion. Several theoretical models argue that multinational firms should generate technology spillovers to local firms through FDI, which is the most important component for a country to attract technology spillovers and benefit from improved technologies as they provide better productivity However, it should be noted that to maximize the absorption of technological spillovers, the domestic country must have a high level of education and training for workers in addition to investment in R\&D.

\section{REFERENCES}

[1] J. B. Robert and X. Sala-i-Martin, "Technological diffusion, convergence and growth," Journal of Economic Growth, vol. 1, pp. 1-26, 1997.

[2] R. Nelson and E. Phelps, "Investment in humans, technological diffusion and economic growth," American Economic Review, vol. 56 pp. 69-75, 1966

[3] M. G. Gene and E. Helpman, "Trade, knowledge spillovers, and growth," European Economic Review, vol. 35, pp. 517-526, 1991.

[4] Borensztein j-1 and P. Mohnen, "International R\&D spillovers between USA and Japenese R\&D intensives sectors," Int. J. Economic, no. 44, 1998.

[5] T. C. David, E. Helpman, and A. W. Hoffmaister, "International R\&D spillovers and institutions," European Economics Review, vol. 53 pp. 723-741, 2009.

[6] R. Griffith, S. Redding, and J. Van Reenen, "R\&D and absorptive capacity: from theory to data," Mimeo, London School of Economics, Nov. 2000b.

[7] W. Keller. (October 2009). International trade, foreign direct investment, and technology spillovers. National Bureal of Economic Research, Working Paper 15442. [Online]. Available: http://www.nber.org/papers/w15442

[8] R. Findlay, "Relative backwardness, direct foreign investment, and th transfer of technology: a simple dynamic model," Quarterly Journal of Economics, vol. 92, pp. 1-16, 1978.

[9] M. Blomstrm and A. Kokko, "Foreign direct investment and spillovers of technology," International Journal of Technology Management, vol. 22, no. 5-6, pp. 435-454, 2001

[10] R. L. Frank and B. V. P. D. L. Potterie, "International R\&D spillovers A comment," European Economic Review, vol. 42, pp. 1483-1491.

[11] H. Elhanan, "R\&D and productivity: the international connection," NBER Working Paper No. 6101, 2007.

[12] B. Javorcik, "Does foreign direct investment increase the productivity of domestic firms? In search of spillovers through backward linkages," American Economic Review, vol. 94, no. 3, pp. 605-627, 2004.

[13] J. Eaton and S. Kortum, "A rising tide raises all ships: trade and diffusion as conduits of growth," NBER Working Paper No. 4931, 1996.

[14] B. Xu, "Multinational enterprises, technology diffusion, and host country productivity growth," Journal of Development Economics, vol. 62 , pp. 477-493, 2000

[15] X. Li and X. Liu, "Foreign direct investment and economic growth: an increasingly endogenous relationship," World Development, vol. 33, pp. 393-407, 2005.

[16] P. Gammeltoft and A. Kokko, "Introduction: outward foreign direct investment from emerging economies and national development strategies: three regimes," Int. Journal of Technological Learning, Innovation and Development, vol. 6, 2013.

[17] G. Blalock and P. J. Gertler, "How firm capabilities affect who benefits from foreign technology," Journal of Development Economics, vol. 90, pp. 192-199, 2009.

[18] R. Belderbos, V. V. Roy, and F. Duvivier, "International and domestic technology transfers and productivity growth: firm level evidence," Oxford Journal, vol. 22, issue 1, 2012.

[19] K. Elmawazini, G. Atallah, S. Nwankwo, and Y. Dissou, "US foreign affiliates, technology diffusion and host country human development: 
human development index versus human capita," Industry and innovation, vol. 20, issue. 1, 2013.

[20] P. Bodman and T. Le, "Assessing the roles that absorptive capacity and economic distance play in the foreign direct investment-productivity growth nexus," Applied Economic, vol. 45, issue 8, 2013.

Imen Daoud Naanaa was born in Tunisia in 1982. She received her master's degree in economics and international finance in 2009 from the Faculty of Economic Sciences and Management of Tunis El Manar (FSEGT), Tunisia and is currently working toward the Ph.D. degree at FSEGT.
Fethi Sellaouti received the Ph.D. degree in 1992 from the University Paris I Panthéon Sorbonne. He is currently a professor at the Faculty of Economic Sciences and Management of Tunis El Manar (FSEGT), Tunisia. His research interests include: monetary theory, money demand and price, Stability and banking risks, prudential regulation, competition, mergers and banking costs, interest rates. 